\title{
Instream ecological flow and reservoir ecological operation in the upper reaches of Irtysh River
}

\author{
Jian $\mathrm{Li}^{1, \mathrm{a}}$, Ziqiang $\mathrm{Xia}^{2}$, Wei Yin ${ }^{1}$ and Haiyan $\mathrm{Jia}^{1}$ \\ ${ }^{1}$ Changjiang Water Resources Protection Institute, Wuhan, 430051, China \\ ${ }^{2}$ College of Hydrology and Water Resources, Hohai University, Nanjing, 210098, China
}

\begin{abstract}
Instream ecological flow (IEF) and flow-related variations were important for healthy river systems. However, water conservancy projects such as reservoirs altered the processes of IEF and thereby posed considerable threat to the health of river systems and aquatic lives. To that end, in this study the effects of reservoir construction on IEF in the upper reaches of the Irtysh River were analyzed using an improved hydrological method. The computed results were in turn used to determine the maximum (MaxIEF), minimum (MinIEF) and optimal (OptIEF) instream ecological flows of the river. Based on the study, reservoir impoundments limited IEF in wet seasons but enhanced it in dry seasons. It also narrowed suitable flow range for reproduction and growth of aquatic life. Reservoirs could be used to regulate Irtysh River discharge. For healthy instream processes in wet years, OptIEF could be set as the lower limit and MaxIEF as the upper limit. For much the same reasons, MinIEF could be set as the lower limit in dry years and OptIEF as a suitable target in normal years.
\end{abstract}

\section{Introduction}

River health very much depended on the characteristics of natural flow regimes (Petts 2009). Aquatic ecosystems required a certain flow volume to maintain growth and reproduction (King et al. 2003). Such flows were usually called environmental flow or instream ecological flow (IEF) conditions. Generally, human activities such as dam construction and water uptake caused various degrees of alteration and destruction to river environment (Assani et al. 2011). To limit river ecosystem disturbance, degradation or to restore river ecosystems, flow quantity and quality standards for minimum river health have been advanced by a number of scholars (Smakhtin et al. 2004). IEF and flow variation characteristics were critical conditions for the protection of healthy river systems (Kumar et al. 2010; Guo et al. 2008).

Over 200 methods have been used in some 44 countries across the globe to evaluate instream environmental flow (Tharme 2003). These methods could broadly be grouped into four categories as hydrological, hydraulic, habitat simulation and holistic approaches. Although the hydraulic approach was computationally simple, it hardly reflected seasonal IEF variation processes (Nelson 1984; Christopher and Michael 1998; Nehring 1979; Kushner 2008). The habitat simulation approach required detailed field work and tedious data verification, which were difficult to be collected (Milhous et al. 1989; Reiser et al. 1989). The holistic approach used multi-disciplinary data approach (such as fish ecology, limnology, botany, etc.), which also made it difficult to use (Arthington et al. 1992; King et al. 2000). However, the hydrological approach [e.g., Tennant method (Tennant 1976), 7Q10 method (Boner and Furland 1982; Caissie et al. 1998) and Texas method (Mathews and Bao 1991)] was computationally simple and easy to handle, and was therefore widely used across the globe (Liu et al. 2011).

Although several IEF computational approaches existed, only few took into account the effects of water conservancy projects on instream ecological flows. As such, most of the IEF computational approaches were generally suitable for either natural river systems or river systems that were little affected by anthropogenic activity (Liu and Men 2007).

From time-to-time changes in river hydrological processes cause random flow variations in short intervals (Wang, 2010). The population structure and life processes of aquatic organisms constantly adapt to instream hydrological regimes (Bunn, 2002). In natural state, any changes in runoff processes trigger corresponding ecological responses. River ecosystems are in constant self-regulating state (Jr, 2004). These features create and sustain micro-aquatic habitats, biodiversity and species population structures in river systems. In a broad sense, IEF is not only about water needs of ecosystems, but also variation characteristics of water temperature, sediment and nutrient load, turbidity, quality and river flow processes. On the one hand, river runoff processes change under anthropogenic disturbances, which affects the structures and functions of river ecosystems. On the other hand, extreme or small

\footnotetext{
${ }^{\text {a }}$ Corresponding author: author@e-mail.org
} 
probability hydrological events such as floods and droughts also affect river ecosystems.

On the basis of the above, the scaled-down mode of IEF proposed by Xia et al. (2007) was used in this study to ensure healthy river ecosystems under extreme or small probability conditions. This sharpened anthropogenic effect assessment of river health and provided reference eco-regulation strategy of water conservancy projects. The narrow sense of the IEF process proposed by Xia et al. (2007) was defined as the flow process that could guarantee the stability and health of river ecosystems under natural conditions. On that basis, IEF is grouped into minimum (MinIEF), maximum (MaxIEF) and optimal (OptIEF) instream ecological flows. MinIEF is the lower limit of flow processes below which the stability and health of river ecosystems cannot be maintained and aquatic creatures cannot survive. The amount of water corresponding to minimum instream ecological flow process is the minimum instream ecological water requirement. MaxIEF is the upper limit of flow processes above which river ecosystem structure can be affected negatively and the stability and health of river ecosystem cannot be maintained. Then OptIEF is the optimal condition flow processes that benefit the stability, biodiversity and health of river ecosystems.

The method used in this study was a new hydrological approach that efficiently determined IEF processes. As the method fully took into account anthropogenic factors, it was suitable for evaluating anthropogenic effects on the health of river systems and aquatic organisms. The IEFs could be used to regulate reservoir operations for optimum desirable effects.

The objective of this research was to assess the impacts of water conservancy projects in the upper reaches of the Irtysh River on downstream IEF processes. To that end, an improved hydrological method was used to evaluate and proposed a suitable upstream reservoir operation strategy for sustainable IEFs in the lower reaches of the Irtysh River.

\section{Materials and methods}

\subsection{Study area}

The study area is the main channel of the upper reaches of Irtysh River, which runs from Buran to Omsk (Fig. 1). There are currently three reservoirs (Bukhtarma, UstKamenogorsk and Shul'binsk reservoirs) along this segment of the channel. The up- and down-streams of the study area are respectively controlled by Buran and Omsk hydro-stations. Buran hydro-station is located at $48.00{ }^{\circ} \mathrm{N}$ and $85.22{ }^{\circ} \mathrm{E}$ in Kazakhstan. It is the control station for flow from China into Kazakhstan. The drainage area of the station is $55900 \mathrm{~km} 2$, accounting for $2.3 \%$ of total Ob-Irtysh drainage area. Annual average discharge from this station is $299 \mathrm{~m} 3 / \mathrm{s}$, accounting for $2.3 \%$ of total flow. Omsk hydro-station, on the other hand, is located at $55.02^{\circ} \mathrm{N}$ and $73.30^{\circ} \mathrm{E}$ in Russia. It is the control station flow from Kazakhstan into Russia. It has a drainage area of $321000 \mathrm{~km} 2$, accounting for $13.2 \%$ of the total river basin. Annual average discharge from this station is $885 \mathrm{~m}^{3} / \mathrm{s}$, which also accounts for $6.9 \%$ of total flow (Yang et al. 2004).

Bukhtarma reservoir, the largest water conservancy project in the Irtysh River, is located in eastern Kazakhstan. The reservoir was constructed in 1953, and started storing water in 1960 . The reservoir capacity and power production are $498 \times 10^{8} \mathrm{~m}^{3}$ and $6.75 \times 10^{8} \mathrm{KW} / \mathrm{yr}$, respectively. With a backwater length of $500 \mathrm{~km}$ and total area of $5490 \mathrm{~km}^{2}$, Bukhtarma reservoir has merged into a single entity with Zaysan Lake (area $1800 \mathrm{~km}^{2}$ ). Bukhtarma reservoir is a carryover storage reservoir, with flood control, power generation, navigation and irrigation functions.

Ust-kamenogorsk reservoir is located in the downstream reaches of Bukhtarma reservoir. The main function of the reservoir is to reverse-adjust unsteady flows from Bukhtarma power plant, which ensures navigation safety. Work on the reservoir started in 1939 and was filled in 1952. The reservoir has a capacity of $6.55 \times 10^{8} \mathrm{~m}^{3}$, power generation of $3.31 \times 10^{8} \mathrm{KW} / \mathrm{yr}$, backwater length of $37 \mathrm{~km}$, and drainage area of $87 \mathrm{~km}^{2}$. Ust-kamenogorsk reservoir is regulated on daily basis and functions as flood control, power generation, navigation and water supply station.

Shul'binsk reservoir is located in the downstream region of Ust-kamenogorsk reservoir. It is also $55 \mathrm{~km}$ upstream of Semipalatinsk in Kazakhstan. The reservoir was built in 1987, with dam length of $570 \mathrm{~m}$, capacity of $24 \times 10^{8} \mathrm{~m}^{3}$ and power production of $7.02 \times 10^{8} \mathrm{KW} / \mathrm{yr}$. Shul'binsk reservoir is a carryover storage reservoir with power generation, irrigation and navigation functions.

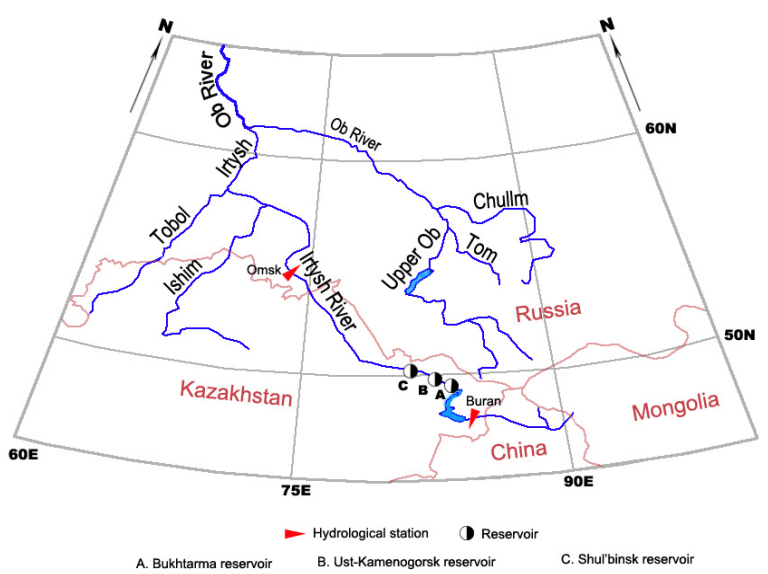

Figure 1. Basic details on the locations of the reservoirs and hydro-stations in the Irtysh River study area of Kazakhstan (adapted after Yang, 2004).

\subsection{Data collection}

The precipitation data from Zaysan (1936-2005), Omsk (1923-2005) hydro-meteorological stations and annual time series discharge data from Buran (1938-2009), Omsk (1923-2004) hydro-stations were used. This data set were further supplemented with monthly time series discharge data from Buran (1938-1990) and Omsk (1923-1990) hydro-stations. Both sets of discharge data were obtained from the R-ArcticNet (version 4.0), which 
was a porter database of the Pan-Arctic River Discharge hosted at http://www.rarcticnet.sr.unh.edu/v4.0/index.ht$\mathrm{ml}$.

\subsection{Methods}

The Omsk hydro-station was used to determine typical reservoir effect of cascade reservoirs on IEF in the downstream reaches of the Irtysh River for a period of three cascades. Similarly, the Buran hydro-station was used to evaluate typical reservoir effect on IEF in the upstream reaches of the Irtysh River. Then the computed IEFs of the representative hydro-stations were compared. For countermeasure strategies to the effects of anthropogenic activity on upstream discharge, the period of change in runoff (runoff slope-break) following the filling of the upstream control station was determined. The runoff conditions after that period were then used to analyze the effect of water conservancy on downstream IEF. Next, time series of the annual runoff were grouped into two based on the slope-break of upstream runoff. Then the difference in IEF between the two subgroups of the runoff time series was analyzed for the hydrostations.

\subsubsection{Runoff slope-break analysis}

The period of runoff slope-break gave a measure of the effect of anthropogenic activity on hydrological time series. The non-parametric Pettitt test (Pettitt 1979) was used in this study to test this effect on the annual runoff time series. This method had a clear physical meaning, clearly pinpointed the period of runoff slope-break, and was therefore often preferred over several methods for analyzing hydrological time series (Pettitt 1980a; 1980b; Rowan and John 2005). The pettitt test used MannWhitney statistical function $\left(U_{\mathrm{t}, T}\right)$ and considers a time series as two samples represented by $x_{1} \cdots x_{t}$ and $x_{t+1} \cdots$ $x_{T}$. For continuous data, the indices and are calculated as:

$$
\begin{gathered}
U_{\mathrm{t}, T}=U_{\mathrm{t}-1, T}+V_{\mathrm{t}, T} \quad(t=2, \ldots, T) \\
V_{\mathrm{t}, T}=\sum_{j=1}^{T} \operatorname{sgn}\left(x_{t}-x_{j}\right)
\end{gathered}
$$

where $\operatorname{sgn}\left(x_{t}-x_{j}\right)=1$ for $x_{t}-x_{j}>0$,

$$
\operatorname{sgn}\left(x_{t}-x_{j}\right)=0 \text { for } x_{t}-x_{j}=0 \text {, and }
$$$$
\operatorname{sgn}\left(x_{t}-x_{j}\right)=-1 \text { for } x_{t}-x_{j}<0 \text {. }
$$

The most significant point of change (in this case runoff slope-break) is at the time where $\left|U_{t, T}\right|$ is maximum; i.e., $K_{T}=\max \left|U_{t, T}\right|$. The approximate significance probability of the change point is calculated as:

$$
P=1-\exp \left[\frac{-6 K_{T}^{2}}{T^{3}+T^{2}}\right]
$$

The zero test of the Pettitt test is assumed to be no mutational. Hence when the significance level is $P<0.95$, the null hypothesis is accepted. When the significance level is $P \geq 0.95$, the null hypothesis is rejected. This implies that there exists a significant change at the change point of the tested time series.

\subsubsection{Monthly discharge coefficient}

An uneven monthly discharge coefficient or the complete adjustment coefficient ( $\left.C_{L}\right)$ describes monthly runoff distribution characteristics. $C_{L}$ is calculated as follows:

$$
C_{L}=\left(\sum_{i=1}^{n} Q_{t}-n Q_{0}\right) / 12 Q_{0}
$$

where $Q_{t}$ is average monthly discharge that is in excess of average annual discharge, $Q_{0}$ is average annual discharge, $n$ is the number of times $Q_{t}$ exceeds $Q_{0}$ in the year. $C_{L}$ fully depicts non-uniformity in monthly discharge. A high $C_{L}$ value indicates a high nonuniformity in monthly discharge, and vice versa.

\subsubsection{An improved hydrological method}

Tenant and monthly minimum (maximum) flow approach is two of most common hydrological methods. However, they are usually used in natural rivers and less take into account the effects of human activities. On the basis of these defects, an improved hydrological method was proposed in this research (Fig. 2). Long term mean monthly discharges were divided into 12 groups in accordance with 12 months. Then, the monthly average flow is calculated as OptIEF, and the monthly minimum or maximum flow is chosen for MinIEF or MaxIEF. Finally, using Tennant method for reference, if the MinIEF is below $10 \%$ of annual average flow, it takes $10 \%$ of annual average flow as MinIEF for keeping river ecosystem health. Similarly, if the MaxIEF is higher than $200 \%$ of annual average flow, the MaxIEF is defined as $200 \%$ of annual average flow.

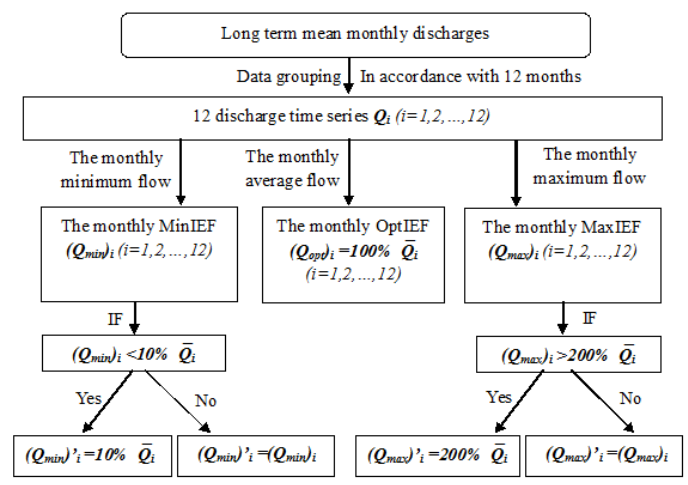

Figure 2. Flowchart of IEFs based on an improved hydrological method. 


\section{Results}

\subsection{Streamflow dynamics}

\subsubsection{Runoff slope-break and reservoir construction}

Pettitt test was used to analyze the points of runoff slopebreak in the annual runoff time series for Buran and Omsk hydro-stations and the results detailed in Table 1. The periods of runoff slope-break were 1959(1973) and 1973 in Omsk and Buran hydro-stations, respectively. In the above periods, the changes in runoff/flow in the hydro-stations were significant at .

Two of three reservoirs between Buran and Omsk hydro-stations started operation after 1959. Therefore the appearance of the runoff slope-break in 1959 was related to the reservoir operation upstream Omsk hydro-station. What's more, there was a same slope-break point between Omsk and Buran hydro-station. It was suggested that the effect of anthropogenic activities becoming more prominent after 1973 in the upper reaches of the Buran hydro-station.

Table 1. Results of Pettitt test for discharge in Buran and Omsk hydro-stations

\begin{tabular}{ccccc}
\hline $\begin{array}{c}\text { Hydro- } \\
\text { station }\end{array}$ & $\begin{array}{c}\text { Data } \\
\text { period }\end{array}$ & $\begin{array}{c}\text { slope-break } \\
\text { point }\end{array}$ & $K_{T}$ & $p$ \\
\hline \multirow{2}{*}{ Buran } & $1938-$ & 1973 & 514 & 0.98 \\
& 2009 & & & \\
Omsk & $1923-$ & 1959 (NO.1) & 917 & 0.99 \\
& 2004 & 1973(NO.2) & 831 & 0.98 \\
\hline
\end{tabular}

The relationship between Buran and Omsk hydrostations in terms of annual flow volume was depicted in Fig. 3. From Fig. 3, it was noticeable that the correlation between annual flow volumes in the hydro-stations before $1959\left(\mathrm{R}^{2}=0.609\right)$ was stronger than that after $1959\left(\mathrm{R}^{2}=0.41\right)$. This suggested that annual flow volumes in the hydro-stations were unevenly destroyed by reservoir operations in the study area.

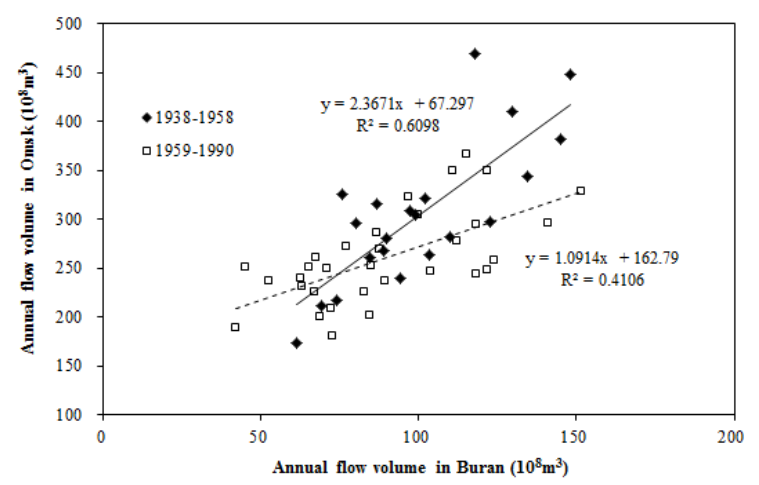

Figure 3. Correlations in annual flow volumes in Buran and Omsk hydro-stations for 1938-1958 and 1959-1990.

\subsubsection{Time series}

Time series of the average annual precipitation tracked rising trends in Zaysan and Omsk stations (Fig. 4). The rising trend in Omsk station $\left(\mathrm{R}^{2}=0.286\right)$ was clearer than that in Zaysan station $\left(\mathrm{R}^{2}=0.022\right)$. Generally, the average annual runoff of the Buran (near Zaysan station) and Omsk stations should have increase trends with the precipitation variation. However, time series of the average annual runoff and the corresponding monthly variation coefficients tracked negative trends (Fig. 5). The negative trends were related to anthropogenic activities such as reservoir impoundment and other forms of river water uptake. There was merely no change in the uneven coefficient of monthly discharge $\left(C_{L}\right)$ in Buran hydro-station for 1939-1990. However, a visible negative trend in $C_{L}$ was noted in Omsk hydro-station for 1923-1990 $\left(\mathrm{R}^{2}=0.304\right)$. Hence the monthly flow process in Omsk hydro-station leveled out with time. This phenomenon could largely be driven by reservoir operation in the upper reaches of Omsk hydro-station.
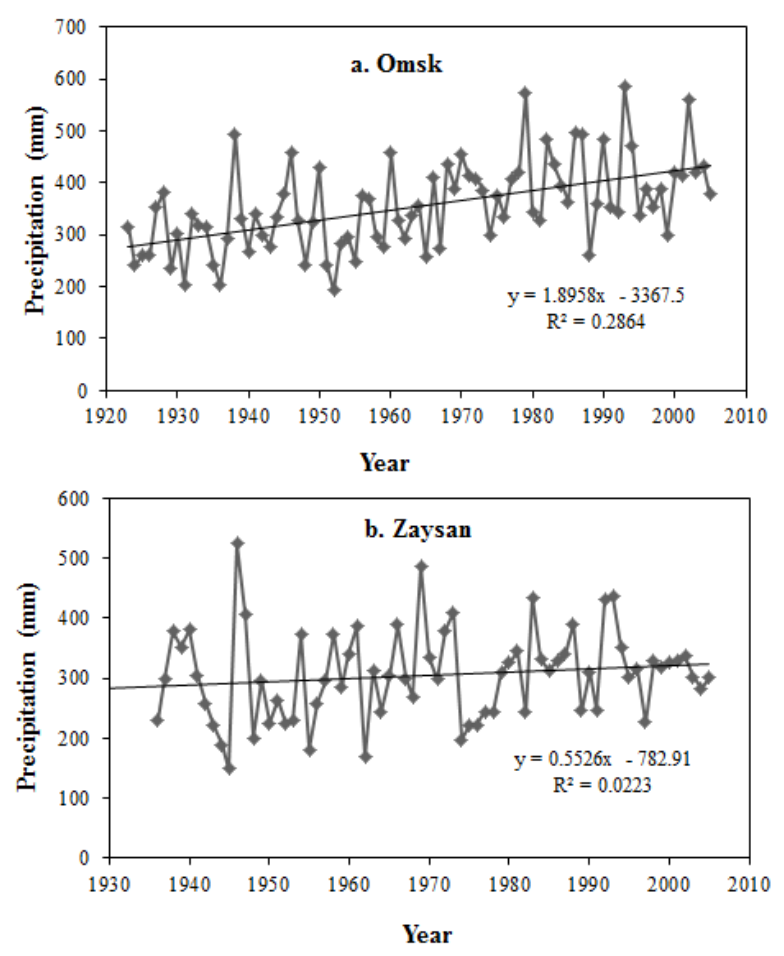

Figure 4. Long-term precipitation and their total trends for the Omsk (a) and Zaysan (b) regions.

\subsubsection{Monthly discharge distribution}

Fig. 6 depicted distributed monthly discharge in Buran and Omsk hydro-stations. The plots denoted estimated natural discharge in Buran hydro-station prior to significant anthropogenic activity in the upstream region. The Buran discharge was in turn used to revise monthly discharge in Omsk hydro-station to the natural conditions.

From Fig. 6a, it was noticeable that the difference in distributed monthly discharge for 1938-1958 was less than that for 1959-1990 in Buran hydro-station. This suggested that the natural restoration analysis was reliable. The discharge difference in Omsk hydro-station (Fig. 6b) was much higher. This suggested that reservoir operations somehow affected distributed monthly 
discharge in Omsk hydro-station. In the study area, discharge generally decreased in wet seasons and increased in dry seasons. In the months of June and July, the decrease in average discharge exceeded $500 \mathrm{~m}^{3} / \mathrm{s}$.
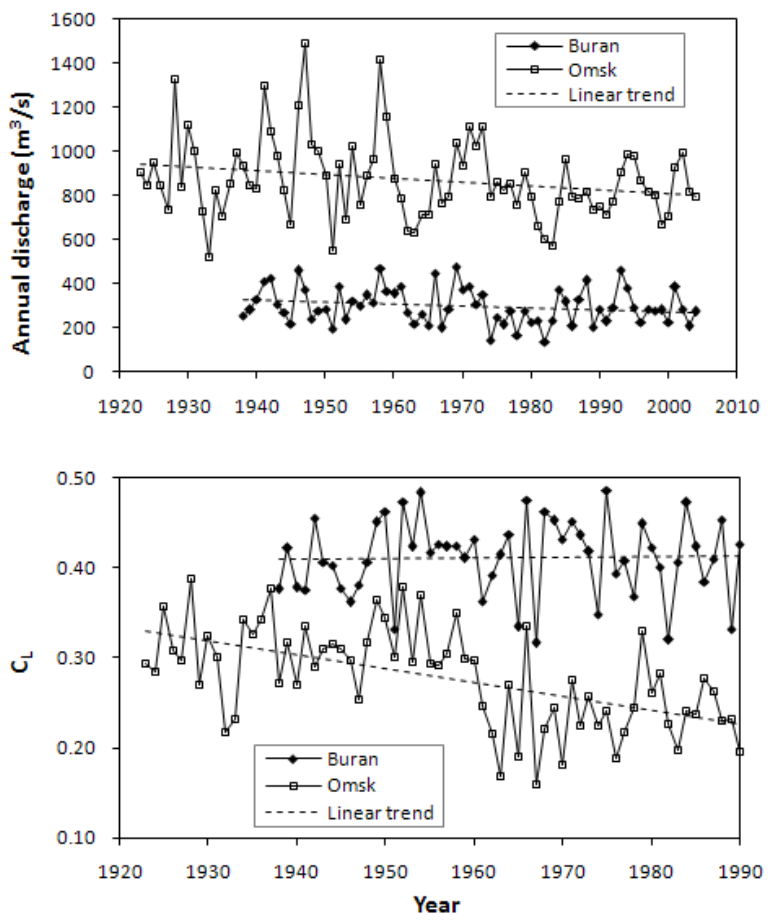

Figure 5. Variation trends in the time series of observed annual discharge and uneven coefficients of monthly discharge $\left(C_{L}\right)$ in Buran and Omsk hydro-stations.

\subsection{Instream eco-flow}

The processes of IEF in Omsk hydro-station were estimated using the improved hydrological method (Fig. 7). The IEF processes before 1959 represents natural requirement for river ecosystem, while the IEF processes after 1959 stands for monthly discharge distribution under the reservoirs operation.

Fig. 7a depicted that MinIEF decreased in May and increased in all other months for the period 1923-1958. The highest difference in flow was in April, during which month about $206 \mathrm{~m} 3 / \mathrm{s}$ increase in MinIEF was noted. Then the highest decline $\left(140 \mathrm{~m}^{3} / \mathrm{s}\right)$ appeared in May.

The processes of OptIEF in Omsk hydro-station were plotted in Fig. 7b. Compared with the period 1923-1958, OptIEF flow in Omsk hydro-station, decreased in May through October after 1959 and increased in all other months. The highest decrease $\left(698 \mathrm{~m}^{3} / \mathrm{s}\right)$ appeared in June and July, and the highest increase appeared in April $\left(219 \mathrm{~m}^{3} / \mathrm{s}\right)$.

The processes of MaxIEF flow in Omsk hydrostation were illustrated in Figs. 7c. As noticeable in Fig. 7c, MaxIEF flow changed considerably after 1959 in Omsk hydro-station. Compared with pre-1959 conditions, MaxIEF flow decreased for May through November post-1959 period. An increasing trend was noted for all other months. The highest change in MaxIEF flow was in June and July, during which months they dropped
$1350 \mathrm{~m}^{3} / \mathrm{s}$ and $1250 \mathrm{~m}^{3} / \mathrm{s}$. The highest increase was in March, when it increased $330 \mathrm{~m}^{3} / \mathrm{s}$.
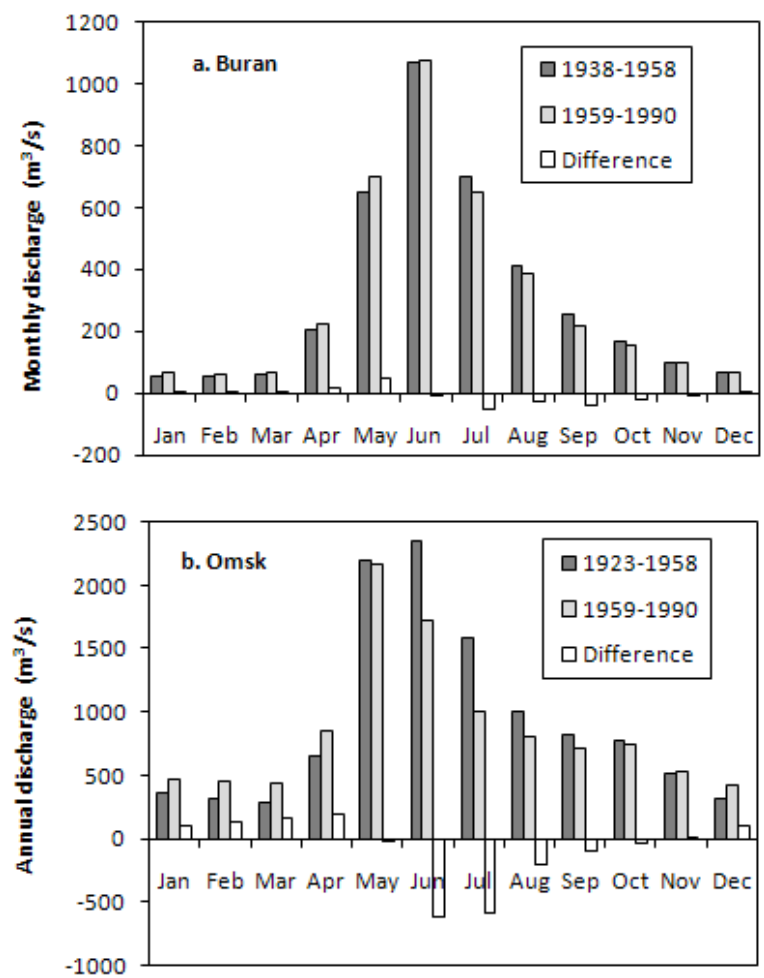

Figure 6. Plots of distributed monthly discharge in Buran and Omsk hydro-stations (the discharges after 1973 were restoring or revised data in computation).
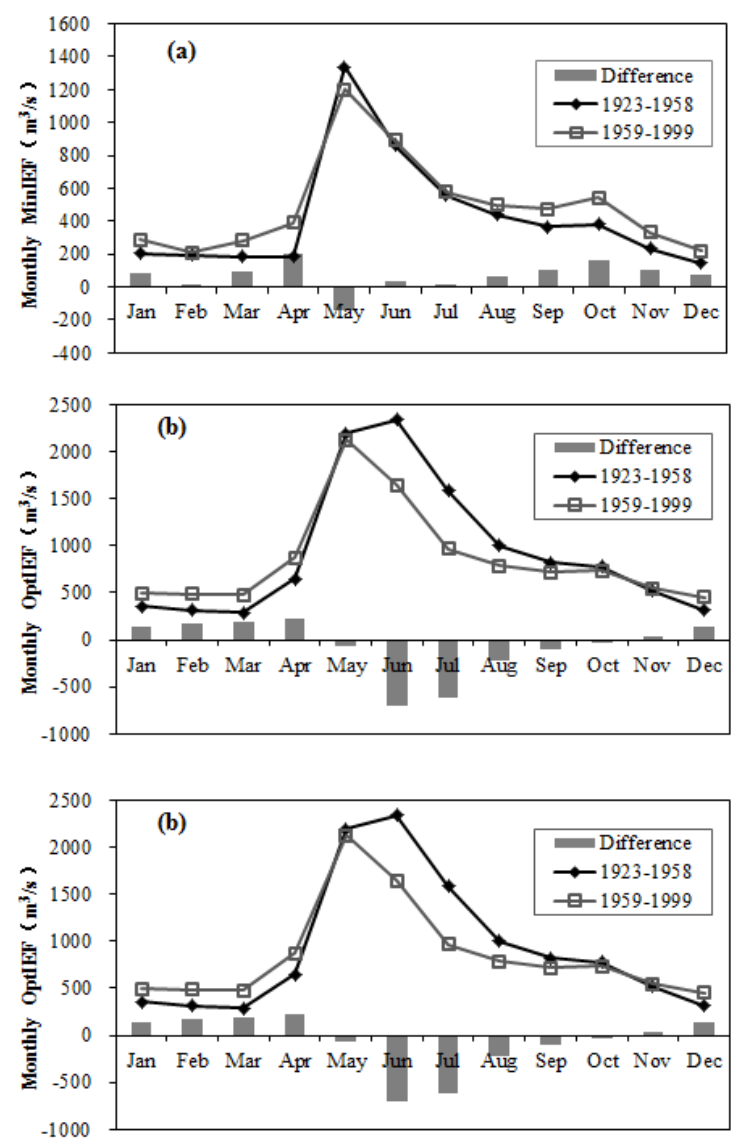

Figure 7. Time series plots of estimated monthly MinIEF, OptIEF and MaxIEF in Omsk hydro-station. 


\section{Discussions}

\subsection{Water conservancy and IEF}

Even with the smoothing out of the impact of anthropogenic activities on runoff in the upstream regions, the cascade of Bukhtarma, Ust-Kamenogorsk and Shul'binsk reservoir operations continued to affect IEF processes downstream of Omsk hydro-station (Fig. 7). After the cascade of reservoir impoundment, IEF decreased in wet seasons and increased in dry seasons. Reservoirs stored part of the water in wet seasons, which caused flood pulse of downstream weakening or disappearance. Study showed that the projects substantial changed in hydrologic regime of the river downstream of the reservoirs and the resulted impact on water regime of flood plains leading to their aridization (Vasiliev 1999). In the Omsk Region (Russian Federation) alone, about 300,000 hectares of floodplain were damaged, including 200,000 hectares of agricultural lands. About $30 \%$ of such land dried up (Vasiliev 1998). On the other hand, the cascade of reservoirs released part of the stored water for electric power generation. This caused the dry season discharge beyond maintaining healthy river natural state.

The cascade of reservoir operations therefore attenuated minimum, maximum and optimal IEF processes after 1959. The monthly IEF processes after the commencement of reservoir operation were more uniform, with an increasingly smaller difference between wet season and dry season flows. The uniform IEF processes caused the flow range that was suitable for stable and healthy river ecosystem narrow. Aquatic life therefore was subjected to more stringent conditions for reproduction and survival. This negatively impacted biomass and biodiversity in the river ecosystem.

The long-term time series data used to determine IEF in this study sufficiently represent flow conditions in the study area. If the cascade of reservoirs in the upstream segment of Omsk hydro-station only targeted power generation and economic benefit then the discharge processes out of safe IEF range could destroy the river ecosystem. It was therefore critical to take into account downstream ecological requirements in the operations of the cascade of reservoirs to ensure that the river ecosystem does not deteriorate beyond current conditions.

\subsection{IEF protection strategy}

Previous analysis show drastic changes in IEF in the downstream region due to upstream reservoir operations. The natural ecosystem was affected by anthropogenic activities, which threatened its survival and sustainability. A sustainable protection strategy should therefore be put in place to ensure safe IEF in Irtysh River. The purpose of the proposed IEF protection strategy was to prevent further deterioration in the current conditions of the river ecosystem.

The main concept of the protection strategy required the estimation of IEF processes that prevent further deterioration in the ecological conditions of the Irtysh River. The estimated IEF took into account natural flow processes and the impact of human activity on those processes. Hence monthly MaxIEF, OptIEF and MinIEF processes were established based on natural and mandriven activities. That was to say, the larger of MaxIEF between natural period and human affected period in each month were picked out to constitute a new MaxIEF process; The smaller of OptIEF between natural period and human affected period in each month were picked out to constitute a new OptIEF process; And the smaller of MinIEF between natural period and human affected period in each month were picked out to constitute a new MinIEF process; Fig. $8 \mathrm{a}$ to $8 \mathrm{c}$ depicted the recommended IEF processes for Omsk hydro-station established on the basis of the above elements. The plots illustrated the natural and man-driven IEF range for healthy river ecosystem.

Under the different flow conditions, the ecological requirements that should be met by the cascade of reservoir operations were best depicted in Fig. 8d. For wet years with $p<25 \%$ flow occurrence frequencies, the lower limit of released discharge from the cascade of reservoirs in study area was set at OptIEF and the upper limit set at MaxIEF processes. For normal years with $25 \% \leq p \leq 75 \%$

OptIEF processes as control objective for upstream reservoirs. Then for dry years with $p>75 \%$ flow occurrence frequencies, the lower limit of released discharge was set at MinIEF processes.

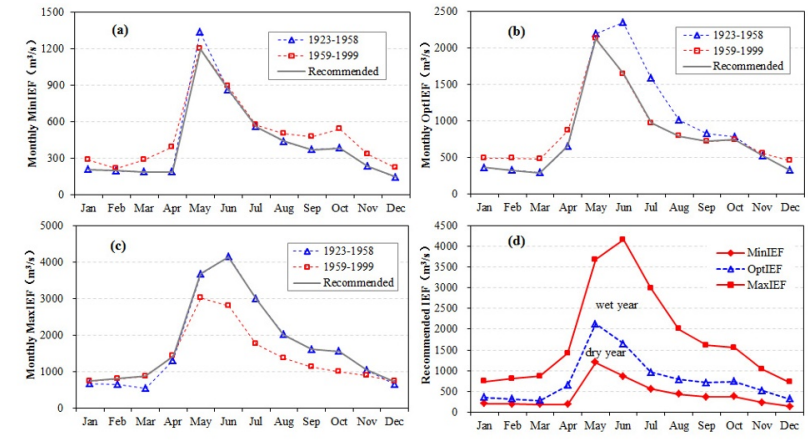

Figure 8. Plots of recommended MinIEF (a), OptIEF (b) and MaxIEF (c) against estimated monthly IEFs for 1923-1958 and 1959-1990; along with a comparison of the three IEF processes (d) in Omsk hydro-station.

\subsection{Comparison of outputted IEF with Tennant approach}

Tennant approach was employed to verify the accuracy of outputted IEF (Table 2). Although there were some shortcomings, the Tennant approach has a macro guidance meaning. Table 2 depicted MinIEF processes were all within acceptable scope of Tennant approach. While OptIEF in May and MaxIEF in May through August exceeded the higher limit of Tennant approach, but they were still no more than $200 \%$ of annual average flow of the same month. On the whole, the outputted 
IEFs used the improved hydrological method in this research were acceptable.

\subsection{Feasibility analysis}

The possibility of predicting "wet", "normal" or "dry" conditions would have to be met as the operation strategy depends on these conditions to set the flow limits. However, how does it kwon the next year is a wet year or a dry year? So the medium and long-term hydrologic forecasting was needed. Only after the occurrence frequency of flow in the future was forecast, which recommended IEF processes in Fig. 8d controlled by upstream reservoirs could be decided to be used. Generally in hydrology, the $p<25 \%$ occurrence frequencies year was wet year, the $25 \% \leq p \leq 75 \%$ occurrence frequencies year was normal year and the $p>75 \%$ occurrence frequencies year was dry year for the flow of hydrological station (Song et al. 2007). Based on the forecast results, the occurrence frequencies of the flow in the next year would be estimated and the water year type would be determined. Then the appropriate range of IEF in the Fig. 8d would be selected to regulate downstream flow through upstream reservoir operation.

Currently, the hydrological forecasting technical can support the estimation for the occurrence frequency of the flow in the future (within a year). The implement condition of recommended IEF protection program downstream reservoirs was available. Therefore, the recommended protection program was also feasible.

$\underline{\text { Table } 2 \text { Assessment of outputted IEF using Tennant approach }}$

\begin{tabular}{|c|c|c|c|c|c|c|}
\hline & Jan & Feb & Mar & Apr & May & Jun \\
\hline MinIEF & 204 & 196 & 186 & 185 & 1200 & 862 \\
\hline $\begin{array}{l}\% \text { of the } \\
\text { average } \\
\text { flow }\end{array}$ & 23 & 22 & 21 & 21 & 137 & 98 \\
\hline $\begin{array}{c}\text { Evaluate } \\
\text { result }\end{array}$ & Good & Good & Good & Poor & $\begin{array}{c}\text { Flushi- } \\
\text { ng }\end{array}$ & $\begin{array}{c}\text { Opti- } \\
\text { mal }\end{array}$ \\
\hline OptIEF & 359 & 317 & 286 & 651 & 2126 & 1646 \\
\hline $\begin{array}{c}\% \text { of the } \\
\text { average } \\
\text { flow }\end{array}$ & 41 & 36 & 33 & 74 & 243 & 188 \\
\hline $\begin{array}{c}\text { Evaluate } \\
\text { result }\end{array}$ & $\begin{array}{l}\text { Outsta- } \\
\text { nding }\end{array}$ & $\begin{array}{l}\text { Exce } \\
\text {-llent }\end{array}$ & $\begin{array}{l}\text { Exce } \\
\text {-llent }\end{array}$ & $\begin{array}{c}\text { Opti- } \\
\text { mal }\end{array}$ & $\begin{array}{l}\text { Flus- } \\
\text { hing }\end{array}$ & $\begin{array}{l}\text { Flus- } \\
\text { hing }\end{array}$ \\
\hline MaxIEF & 742 & 807 & 866 & 1425 & 3680 & 4150 \\
\hline $\begin{array}{c}\% \text { of the } \\
\text { average } \\
\text { flow }\end{array}$ & 85 & 92 & 99 & 163 & 420 & 473 \\
\hline \multirow[t]{2}{*}{$\begin{array}{c}\text { Evaluate } \\
\text { result }\end{array}$} & $\begin{array}{l}\text { Optim- } \\
\text { al }\end{array}$ & $\begin{array}{c}\text { Opti- } \\
\text { mal }\end{array}$ & $\begin{array}{l}\text { Opti- } \\
\text { mal }\end{array}$ & $\begin{array}{l}\text { Flus- } \\
\text { hing }\end{array}$ & $\begin{array}{l}\text { Flush- } \\
\text { ing }\end{array}$ & $\begin{array}{l}\text { Flus- } \\
\text { hing }\end{array}$ \\
\hline & Jul & Aug & Sep & Oct & Nov & Dec \\
\hline MinIEF & 558 & 437 & 368 & 382 & 231 & 144 \\
\hline $\begin{array}{c}\% \text { of the } \\
\text { average } \\
\text { flow }\end{array}$ & 64 & 49 & 42 & 44 & 26 & 16 \\
\hline
\end{tabular}

\begin{tabular}{|c|c|c|c|c|c|c|}
\hline $\begin{array}{c}\text { Evaluate } \\
\text { result }\end{array}$ & $\begin{array}{l}\text { Optim- } \\
\text { al }\end{array}$ & Good & Good & $\begin{array}{c}\text { Outsta- } \\
\text { nding }\end{array}$ & Good & Fair \\
\hline OptIEF & 967 & 786 & 716 & 739 & 519 & 318 \\
\hline $\begin{array}{c}\% \text { of the } \\
\text { average } \\
\text { flow }\end{array}$ & 110 & 90 & 82 & 84 & 59 & 36 \\
\hline $\begin{array}{c}\text { Evaluate } \\
\text { result }\end{array}$ & $\begin{array}{c}\text { Flushi- } \\
\text { ng }\end{array}$ & $\begin{array}{c}\text { Opti- } \\
\text { mal }\end{array}$ & $\begin{array}{c}\text { Opti- } \\
\text { mal }\end{array}$ & $\begin{array}{l}\text { Optim- } \\
\text { al }\end{array}$ & $\begin{array}{c}\text { Outsta- } \\
\text { nding }\end{array}$ & $\begin{array}{l}\text { Exce } \\
\text {-llent }\end{array}$ \\
\hline MaxIEF & 2990 & 2008 & 1610 & 1557 & 1037 & 726 \\
\hline $\begin{array}{c}\% \text { of the } \\
\text { average } \\
\text { flow }\end{array}$ & 341 & 229 & 184 & 178 & 118 & 83 \\
\hline $\begin{array}{c}\text { Evaluate } \\
\text { result }\end{array}$ & $\begin{array}{l}\text { Flush- } \\
\text { ing }\end{array}$ & $\begin{array}{l}\text { Flus- } \\
\text { hing }\end{array}$ & $\begin{array}{l}\text { Flus- } \\
\text { hing }\end{array}$ & $\begin{array}{l}\text { Flush- } \\
\text { ing }\end{array}$ & $\begin{array}{l}\text { Flush- } \\
\text { ing }\end{array}$ & $\begin{array}{c}\text { Opti- } \\
\text { mal }\end{array}$ \\
\hline
\end{tabular}

\section{Conclusions}

Anthropogenic activities were critical elements influencing IEF processes, which in turn negatively affect the river ecosystem. Analyzing the processes and range of required IEF for stable and healthy river conditions was vital for river ecosystem protection and sustainability. An improved hydrological method was used in this study to analyze IEF processes before and after the commencement of operations of a cascade of reservoirs along the Irtysh River. Then minimum, optimal and maximum instream ecological flows that prevent further deterioration in current conditions in the river ecosystem were established. The estimated IEF processes included natural IEF and man-driven IEF river ecosystem requirements. The findings of the study played a reference for ecological flow regulation of the three reservoirs in the upper Irtysh River.

The hydrological approach based on the Tennant method only analyzed the effect of the hydrological processes on river health. It did not account for water quality, sediment, nutrient load and other environmental factors. Moreover, because only the monthly discharge prior to 1990 was used, the precision of the analysis could somehow be compromised. It was therefore recommended that much longer-term time series hydrological data (including irrigation water uptake, etc.) be used in future studies.

In addition, all calculation in this research were based on hydrological approach, and none biological monitoring data of the Irtysh River was involved. In the afterward research, the target species would be chose and the new IEF processes would be calculated by ecohydraulic method. Then the comprehensive results that calculated by hydrological approach and eco-hydraulic method would be more helpful to river health.

\section{Acknowledgement}

This study was supported by the National Key Research and Development Program of China (2017YFC0404502). We thank the R-ArcticNet for providing the supporting 
data, and also acknowledge the support of the technical staff.

\section{References}

1. A.H. Arthington, J.M. Kingm, J.H. O'Keeffem, The Centre for Water Policy Research, University of New England, Armidale, Australia. (1992)

2. A.A. Assani, R. Landry, J. Daigle, A.Chalifour, Water Resour. Manage., 25 (2011)

3. M.C.Boner, L.P. Furland, J. Water Pollut. Contr. Federation, 54(1982)

4. S.E. Bunn, A.H. Arthington, Environ. Manage, 30(2002)

5. D. Caissie, , N. EI-Jabi, G. Bourgeois, J. Water Sci., 11 (1998)

6. J.G. Christopher, J.S. Michael, Regul. Rivers: Res. \& Manage., 14(1998)

7. L.D. Guo, Z.Q. Xia, J. Li, G.H. Mar, J. Hohai Univ. (Natural Sciences) (2008)

8. J.C. Jr, Int. J. Sustain. Dev. World Ecol., 11 (2004)

9. J. King , C. Brown, H. Sabet, River Res. Appl., 19(2003)

10. J.M. King, R.E. Tharme, M. De Villiers, Water Research Commission Technology Transfer Report No. TT131/00. Water Research Commission, Pretoria, South Africa. (2000)

11. D.N. Kumar , F. Baliarsingh, K.S. Raju, Water Resour. Manage., 24 (2010)

12. R. Kushner,. Newfoundland, 973(2008)

13. C.M. Liu , C.S. Zhao, J. Xia, C.L. Sun, R.Wang, T. Liu, J. Hydrol., 398 (2011)

14. C.M. Liu, B.H. Men, Prog. Nat. Sci., 17 (2007)

15. R.C. Mathews, Y.X. Bao, Rivers, 2 (1991)

16. R.T. Milhous, M.A. Updike, D.M. Schneider, Instream Flow Information Paper 26. (1989)

17. R.B. Nehring, Division of Wildlife, Fort Collins, Colorado. (1979)

18. F.A. Nelson, Montana. Department of Fish, Wildlife, and Parks, Bozeman, Montana. (1984)

19. A.N. Pettitt, J. Appl. Stat., 28 (1979)

20. A.N. Pettitt, Biometrika, 67 (1980a)

21. A.N. Pettitt, J. Stat. Comput. Sim., 11(1980b)

22. G.E. Petts, J. Am. Water Resour. Asssoc., 45 (2009)

23. D.W. Reiser, T.A. Wesche, C. Estes, Fisheries, 14 (1989)

24. V.Smakhtin, C. Revenga , P. Doll, Comprehensive Assessment Secretariat, Colombo, Sri Lanka. (2004)

25. J.X. Song, Z.X. Xu, C.M. Liu, H.E. Li, Hydrol. Process., 21 (2007)

26. D.L. Tennant, In: Orsborn, J.F., Allman, C.H. (Eds.), Proceedings of Symposium and Speciality Conference on Instream Flow Needs II American Fisheries Society, (1976)
27. R.E. Thame, River Res. Appl., 19(2003)

28. O.F. Vasiliev, Restoration of Degraded Rivers: Challenges,Issuses and Experiences. (1998)

29. O.F. Vasiliev, XXIX IAHR Congress proceedings: Development, Plainning and Management of Surface and Ground Water Resources (1999)

30. D. Wang, Human and Ecological Risk Assessment, $16(2010)$

31.Z.Q. Xia , Q.F. Li, L.D. Guo, J. Li, W. Zhang, H.Q. Wang, IAHS Publ. 315(2007)

32. D.Q.,Yang, B.S. Ye, A. Shiklomanov, J. Hydrometeorol., 5 (2004) 